\title{
Penelitian Kombinasi habBatus sauda (NIGElla sativa) DAN MADU SEBAGAI ALTERNATIF TOPIKAL PERAWATAN ULKUS DIABETIK Nova Friska
}

Fakultas Keperawatan, Universitas Syiah Kuala

\begin{abstract}
Abstrak
Diabetes mellitus merupakan salah satu penyakit yang prevalensinya terus meningkat setiap tahunnya. Ulkus diabetik adalah salah satu komplikasi yang disebabkan oleh diabetes mellitus. Banyak efek yang ditimbulkan oleh ulkus diabetik diantaranya meningkatnya risiko amputasi, menurunkan kualitas hidup pasien dan risiko harga diri rendah pun rentan terjadi. Banyak metode yang telah digunakan untuk menyelesaikan masalah ulkus diabetik, diantaranya menggunakan ekstrak cacing tanah (Pheretima aspergillum ). Penelitian yang telah dilakukan menunjukkan bahwa pemberian ekstrak cacing tanah dapat meningkatkan persentase kontraksi luka dan densitas akson perifer pada ulkus diabetik. Namun tak semua pasien bersedia melakukan perawatan dengan menggunakan esktrak cacing tanah. Hal tersebut bisa dikarenakan rasa ketidaksukaan yang timbul pada cacing. Oleh karena itu, penelitian terkait perawatan Ulkus diabetik dengan menggunakan habbatus sauda dan madu dapat menjadi salah satu solusi. Penelitian yang telah dilakukan sebelumnya tidak menggunakan kombinasi antara keduanya melainkan hanya salah satunya saja. Penulis menawarkan ide berupa kombinasi antara habbatus sauda dan madu sebagai alternatif topikal ulkus diabetik. Dalam melakukan penatalaksanaan ulkus diabetik, terdapat tiga prinsip utama manajemen Ulkus diabetik yaitu debridement, off-loading dan control infeksi. Berdasarkan prinsip utama manajemen Ulkus diabetik, madu berperan dalam prinsip debridement. Madu memiliki sifat yang lembab (moist) sehingga proses debridement mudah dilakukan serta mempercepat reepitelisasi jaringan. Habbatus sauda berguna dalam proses control infeksi. Kandungan senyawa aktif thymoquinone yang terdapat didalamnya berperan sebagai antibakteri dan antiimflamasi sehingga dapat menjadi antimicrobial pada ulkus diabetic. Sedangkan off-loading tidak menjadi fokus penulis dikarenakan manajemen off-loading bergantung kepada aktivitas pasien dalam keseharian. Kombinasi habbatus sauda dan madu dapat digunakan sebagai alternatif topical dalam perawatan ulkus diabetik dikarenakan pada habbatus sauda dan madu terdapat komponen yang dibutuhkan dalam manajemen ulkus diabetik. Waktu yang dibutuhkan untuk menyembuhkan ulkus diabetic menggunakan habbatus sauda dan madu sangat bergantung kepada grade ulkus diabetic, semakin kecil grade ulkus maka semakin cepat proses penyembuhan terjadi. Desain dalam penelitian ini adalah quasy experiment dengan kelompok pembanding (control time series design). Rekomendasi dari penulisan ini adalah adanya penelitian lanjutan terkait kombinasi habbatus sauda dan madu sebagai salah satu alternatif topical untuk mempercepat penyembuhan ulkus diabetik.
\end{abstract}

Kata kunci : Madu, Habbatus sauda, ulkus diabetik, rawat luka

\section{Abstract}

Diabetes mellitus is one of the diseases that the prevalence keeps increasing annually. Diabetic ulcer is one of complications caused by diabetes mellitus. Diabetic ulcer gives many impacts to the patients such as increase of amputation risk, risk of low self esteem and the decrease of patient's life quality. Many methods have been used to treat diabetic ulcer, which of one of the use of the extract of earthworms (Pheretima aspergillum). The research indicated that using of the extract increase presentation of wound contraction and density axons peripheral. However, not all patients want to use this treatment as their solution. It might be this treatment with this way make them disgusted. The other research give the different solution, those are habbatus sauda and honey. All the previous researchers never conducted intergratedly but separatedly. In this paper, the writter purposes a combination of both habbatus sauda and honey as alternative of diabetic ulcer. In the treatment of this disease, they are three main management principles of diabetic ulcer; debridement, off loading and infection control. Based on those principle, honey's role is very effective in debridement. Honey has a moist nature (moist) so that the debridement process is easy to do and speed up reepitelisasi. Habbatus sauda functionates in the last principle, infection control. The content of thymoquinone active compounds contained therein act as antibacterial and antiimflamasi so that it can become antimicrobial in diabetic ulcers. Howover, the writter doesn't concern with the second principle (off loading) because this principle is more focus on patient activities. The combination of habbatus sauda and honey can be used as a topical alternative in the treatment of diabetic ulcers because of the habbatus sauda and honey there are components needed in the management of diabetic ulcers. The time taken to cure diabetic ulcers using habbatus sauda and honey is dependent on the grade of diabetic ulcers, the smaller the grade of ulcers the faster the healing process occurs. The design in this research is quasy experiment with the control group (control time series design). Recommendation of this writing is the existence of advanced research related to combination of habbatus sauda and honey as one of topical alternative to accelerate healing diabetic ulcers

Keyword : Honey, Habbatus sauda, diabetic ulcer, wound care 


\section{PENDAHULUAN}

Diabetes mellitus (DM) merupakan salah satu isu kesehatan global yang setiap tahunnya terus mengalami peningkatan prevalensi penderita. International Diabetes Federation (IDF) menyatakan bahwa pada tahun 2013 terdapat sekitar 382 juta penduduk dunia yang mengidap diabetes mellitus dan diperkirakan prevalensinya akan terus meningkat mencapai 592 juta jiwa pada tahun 2035 2 . Intremational Diabetes Federation Westem Pasific Region (IDF.

WPR) menyatakan diperkirakan pada tahun 2015 terdapat 9,1 juta masyarakat Indonesia yang menderita diabetes mellitus.

Dunning (2003) mendefenisikan diabetes mellitus sebagai gangguan sistem endokrin dengan adanya peningkatan kadar gula darah yang berhubungan dengan gangguan produksi insulin dan metabolisme glukosa ${ }_{6}$. Adib (2011) menyatakan jika diabetes mellitus merupakan salah satu penyakit yang paling banyak memiliki komplikasi. Hal ini berkaitan dengan kadar gula darah yang terus meningkat, sehingga mengakibatkan rusaknya pembuluh darah saraf dan struktur internal lainnya ${ }^{5}$. Salah satu komplikasi Diabetes mellitus adalah Ulkus diabetik.

Ulkus diabetik merupakan salah satu komplikasi kronis Diabetes mellitus dengan prevalensi yang terus meningkat setiap tahunnya. Hastuti (2008) menyebutkan bahwa prevalensi penderita ulkus diabetik di Amerika Serikat sebesar $15-20 \%$ dengan risiko amputasi 15-46 kali lebih tinggi

dibandingkat penderita non-diabetes mellitus 14. Sedangkan di Indonesia, Soegondo (2009) menyebutkan bahwa prevalensi penderita ulkus diabetik sekitar $15 \%$ dengan angka amputasi $30 \%{ }_{13}$. Selain risiko amputasi, ulkus diabetik mempunyai angka mortalitas yang cukup tinggi. Hastuti (2008) menyebutkan, di Indonesia angka mortalitas pasien yang ${ }_{14}$ mengalami ulkus diabetik sebesar $32 \% 14$.

Tiokropawiro (2007) mendefenisikan ulkus diabetik sebagai luka pada kaki dengan karakteristik merah kehitaman yang berbau busuk diakibatkan adanya sumbatan di pembuluh darah ditungkai ${ }^{17}$. Jika tidak dilakukan perawatan luka dengan baik akan mengakibatkan ulkus berubah menjadi nekroktik yang akhirnya dapat membuat pasien berisiko untuk diamputasi

Ulkus diabetik merupakan salah satu penyebab lamanya rawatan inap pasien di rumah sakit. Hastuti (2008) menyebutkan bahwa $80 \%$ penyebab lamanya rawatan adalah akibat ulkus diabetik ${ }^{14}$. Hal tersebut mengakibatkan meningkatnya beban biaya rawatan yang harus ditanggung oleh pasien dan keluarga. Ridwan (2011) menyatakan bahwa setiap penderita ulkus diabetik di Indonesia harus mengeluarkan biaya sebesar 1,3 juta sampai 1,6 juta perbulan dan 43,5 juta untuk seorang penderita 8 . Tingginya biaya perawatan yang harus ditanggung pasien tidak hanya membebani pasien dan keluarga melainkan juga negara.

Lamanya rawatan inap pasien di rumah sakit akan mengakibatkan produktivitas dan kualitas hidup pasien menurun. Marvinia (2013) menyebutkan bahwa lamanya masa rawatan akibat ulkus diabetik akan berpengaruh terhadap kualitas hidup pasien. Selain biaya yang cukup tinggi, lamanya masa rawatan juga akan mempengaruhi psikologis pasien. Sehingga akan semakin menurunkan kualitas hidup pasien.

Sudah banyak solusi yang ditawarkan untuk mengatasi ulkus diabetik. Salah satunya adalah menggunakan ekstrak cacing tanah. Penelitian yang dilakukan Mardiati et al (2013) menunjukkan bahwa pemberian ekstrak cacing tanah (Pheretima aspergillum) dapat meningkatkan persentase kontraksi luka dan densitas akson perifer pada ulkus diabetik. Dengan demikian Pheritema aspergillum memiliki potensi sebagai standar perawatan Ulkus diabetik. Namun tidak semua pasien mau menggunakan metode ini sebagai solusi dikarenakan penggunaan ekstrak cacing tanah yang tidak banyak disukai.

Penelitian lainnya juga dilakukan untuk menyelesaikan ulkus diabetik diantaranya dengan menggunakan madu dan habbatus sauda sebagai alternatif. Hal tersebut dihubungkan dengan komponen di dalam habbatus sauda dan madu yang sesuai dengan prinsip utama manajemen ulkus diabetik. Menurut pendapat beberapa ahli Jeffcoate (2003), Delmas (2006), Kruse (2006), dan Clayton (2009), dalam melakukan penatalaksanaan ulkus diabetik, terdapat tiga prinsip utama manajemen ulkus diabetik yaitu debridement, off-loading dan control 16. Berdasarkan prinsip utama manajemen ulkus diabetik, madu berperan dalam prinsip debridement. Sifat madu yang lembab membuat proses debridement mudah dilakukan serta dapat

mempercepat re-epitelisasi jaringan. Sedangkan habbatus sauda berguna dalam 
proses control infeksi dikarenakan kandungan senyawa aktif thymoquinone yang berperan sebagai antibakteri dan antiimflamasi sehingga dapat menjadi antimikrobial pada kondisi ulkus diabetik.

Tujuan dari penulisan ini adalah menawarkan alternatif perawatan topikal ulkus diabetik yang merupakan salah satu komplikasi diabetes mellitus. Sedangkan manfaat yang dapat diperoleh berupa sebagai salah satu alternatif dalam perawatan ulkus diabetik, meminimalisir

terjadinya amputasi dan kematian dikarenakan perawatan ulkus diabetik yang tidak tepat

\section{METODE PENELITIAN}

Peneliti menggunakan desain
penelitian quasy experiment dengan kelompok pembanding (control time series design). Populasi dalam penelitian ini adalah pasien RSU dr.Zainal Abidin banda Aceh yang dirawat dengan ulkus diabetic. Pada kelompok kontrol akan diberikan alternatf topical perawatan ulkus diabetic berupa kombinasi habbatus sauda dan madu sedangkan pada kelompok pembanding adalah pasien yang tidak mendapat perawatan alternatif menggunakan habbatus sauda dan madu.

\section{PEMBAHASAN}

Salah satu bentuk upaya mencegah memburuknya kondisi ulkus adalah jenis perawatan yang digunakan. Depkes (2010) mengungkapkan bahwa para ahli diabetes memperkirakan $1 / 2$ sampai $3 / 4$ kejadian amputasi dapat dihindari dengan perawatan luka yang baik ${ }^{8}$. Diantara bentuk perawatan ulkus diabetik tersebut adalah dengan menerapkan manajamen perawatan ulkus diabetik. Menurut pendapat beberapa ahli Jeffcoate (2003), Delmas (2006), Kruse (2006), dan Clayton (2009), dalam melakukan penatalaksanaan ulkus diabetik, terdapat tiga prinsip utama manajemen ulkus diabetik yaitu debridement, off-loading dan control 16 .

Selain itu hasil penelitian Wijonarko (2004) tentang efektivitas teknik dressing ulkus diabetik juga menunjukkan bahwa luka ulkus akan mengalami kesembuhan 90\% apabila dilakukan terapi secara komprehensif diantaranya dengan cara menjaga luka agar selalu lembab (moist), penanganan infeksi dan ${ }^{8}$.

Madu berperan pada prinsip debridement. Penelitian sebelumnya yang dilakukan oleh Abidin (2014) menunjukkan bahwa madu menghasilkan suatu zat kimia untuk 1. Abidin (2014) juga mengungkapan bahwa proses debridement luka pada pasien yang dirawat menggunakan madu sangat mudah diangkat dan dibersihkan, jaringan nekrotik berupa gumpalan debris berwarna putih kekuningan dan berserabut sangat mudah terangkat dari dasar luka 1. Intanwidya (2005) menyatakan jika madu juga merangsang tumbuhnya jaringan baru, sehingga selain mempercepat penyembuhan juga mengurangi timbulnya jaringan parut atau bekas luka pada kulit ${ }^{1}$. Al -Fady (2012) menambahkan sebagai agen pengobatan luka topikal, madu mudah diserap kulit, sehingga dapat menciptakan kelembaban kulit dan memberi nutrisi yang dibutuhkan 1 .

Perawatan luka yang efektif menurut The Journal of Familiy Practice (2005) adalah dengan cara mengkondisikan luka agar tetap lembab sehingga dapat mengurangi nyeri serta meningkatkan sirkulasi 8 . Hal ini menunjukkan bahwa sifat madu yang lembab dapat memudahkan tindakan debridement dan meransang percepatan penyembuhan luka dikarenakan madu mampu merangsang tumbuhnya jaringan baru.

Selanjutnya prinsip manajemen ulkus diabetik yang kedua yaitu off-loading. Slater (2001) mendefenisikan off-loading sebagai upaya untuk mencegah tekanan yang berlebihan pada ulkus 16. Keast (2000) menyebutkan tujuan off-loading adalah mendistribusi tekanan dari daerah ulkus ke area yang lebih luas 16. Frykberg (2002) dan Kruse (2006) menyatakan bahwa tekanan yang diakibatkan oleh stress mekanikal pada ulkus dapat menghambat penyembuhan bahkan dapat memperparah kondisi ulkus hingga menjadi gangrene 16. Prinsip yang kedua tidak menjadi fokus penulis dikarenakan prinsip ini tidak berhubungan dengan kondisi ulkus yang membutuhkan perawatan secara topikal melainkan bergantung kepada aktivitas pasien.

Habbatus sauda dalam manajemen ulkus diabetik berfungsi sebagai control infeksi dikarenakan aktivitas antimikroba yang dimiliki ${ }^{4}$. Salah satu kandungan yang terdapat di dalam habbatus sauda adalah senyawa aktif thymoquinone. Thmoquinone

memiliki efek antibakterial terhadap Staphylococcus aureus, Pseudomonas aeruginosa dan Eschericia $(4,7,11)$.

Penelitian Halawani (2009)

juga 
menghasilkan kesimpulan bahwa ekstrak minyak atsiri habbatus sauda jika digabungkan dengan antibiotik akan memiliki aktivitas antimikroba yang lebih besar besar

Kondisi ulkus diabetik sangat rentan terinvasi oleh bakteri. Waspadji (2007) menyatakan bahwa Staphylococcus aereus yang asalnya adalah flora normal dapat menjadi patogen ketika berada di lokasi ulkus 5. Beberapa bakteri patogen terbanyak yang ditemukan pada kondisi Ulkus diabetik adalah Klebsiella sp., Proteus mirabilis, Staphylococcus aureus dan Escherichia ${ }^{(9,14)}$. Kesesuaian daya mikrobial bakteri tertentu yang dimiliki habbatus sauda dan bakteri yang terdapat pada kondisi ulkus diabetik mengakibatkan habbatus sauda efektif dan dapat dijadikan sebagai alternatif topikal pada perawatan ulkus diabetik

Selain sesuai dengan prinsip utama manajemen ulkus diabetik, aplikasi topikal habbatus sauda mempercepat penyembuhan luka. Efek penyembuhan luka dari habbatus sauda terkait dengan adanya antioksidan, antibakteri, dan antiınflamasi yang terdapat di dalam senyawa aktif $h$

Hasil penelitian yang dilakukan Yulistiani (2015) menunjukkan adanya penurunan proses imflamasi dan percepatan proses penyembuhan luka pada ulkus diabetik setelah dilakukan pemberian habbatus sauda 10\%. Pemberian habbatus sauda $10 \%$ ini membantu proses penyembuhan luka terutama pada fase imflamasi. Pada fase imflamasi, habbatus sauda berperan mengatasi peradangan peradangan 17 . Labeb Salem Mohammaed (2005) di dalam Yuliatini (2015) menyatakan bahwa habbatus sauda dapat menurunkan peradangan dikarenakan kandungan senyawa aktif thymoquinone yang terdapat didalamnya ${ }^{17}$.

$$
\text { Perdanakusuma DS }
$$

menyatakan, umumnya fisiologis penyembuhan luka secara alami akan mengalami 3 tahapan fase yaitu fase imflamasi, fase proliferasi dan fase

maturasi 17. Habbatus sauda yang mempunyai aktivitas sebagai antiimflamasi berperan untuk mencegah terjadinya peradangan pada fase imflamasi. Luka adalah kondisi yang sangat rentan

mengalami infeksi akibat aktivitas mikrobacterial patogen. Habbatus sauda dan madu memiliki aktivitas antibakteri sehingga dapat membunuh bakteri patogen yang menyebabkan infeksi pada ulkus diabetik.
Pada fase proliferasi, madu merangsang

tumbuhnya jaringan baru sehingga mempercepat penyembuhan luka. Selain itu madu madu mudah diserap kulit, sehingga dapat menciptakan kelembaban kulit dan memberi nutrisi yang dibutuhkan.

Pearson (2006) mengungkapkan pemilihan balutan dan jenis perawatan ulkus mempengaruhi proses penyembuhan ulkus 16. Oleh karena itu, perawatan Ulkus diabetik dengan menggunakan kombinasi madu dan habbatus sauda dapat menjadi pilihan sebagai alternatif untuk mempercepat penyembuhan ulkus diabetik. Madu dapat dijadikan sebagai dressing yang akan membuat luka tetap dalam keadaaan lembab sedangkan habbatus sauda dapat menggantikan antibakteri yang saat ini digunakan.

Cara mengaplikasikan kombinasi ini adalah jika habbatus sauda sesuai penelitian yang dilakukan oleh Yulistiani (2015), dilakukan intervensi dengan cara mengolesi habbatus sauda pada luka dengan menggunakan catton buth, dengan ketebalan salep $(1 \mathrm{~mm})$ melingkar dari tengah keseluruh area luka searah jarum jam 19 . Setelah itu luka ditutup dengan menggunakan dressing atau balutan yang telah direndam dengan menggunakan madu seama waktu yang telah ditentukan.

Salah satu faktor yang mempengaruhi penyembuhan luka adalah derajat atau grade dari luka itu sendiri" ${ }^{14}$. Penelitian yang dilakukan oleh Pramana, dkk (2012) menunjukkan pada responden yang memiliki ulkus diabetik grade 1 dan grade 2, didapatkan hasil pada hari ke-7 pemberian madu, semua responden memiliki perubahan luka yang baik, diantaranya adanya jaringan granulasi baru, tidak ada reaksi imflamasi dan luka mengering ${ }^{14}$.

Begitu pula dengan habbatus sauda. Penelitian yang dilakukan Yuliastiani (2015) menunjukkan terdapat perbedaan kondisi luka pada pre dan post pemberian habbatus sauda selama 14 hari. Perkembangan luka dilihat dari jumlah skore luka yang diperoleh, skore luka regenerasi adalah skore 1-13 dan skore luka degenerasi yaitu 14-60, dimana skore maksimal adalah 65 yang merupakan wujud proses penyembuhan luka kurang dari $50 \% \%^{17}$

Penelitian tentang penggunaan habbatus sauda dan madu sebaga alternative perawatan ulkus diabetik telah banyak dilakukan. Hanya saja penelitian yang dilakukan sebelumnya tidak 
mengkombinasikan penggunaan keduanya sebagai alternatif perawatan, melainkan digunakan secara terpisah. Oleh karena itu, penulis mengharapkan adanya penelitian terkait keefektifan penggunaan kombinasi habbatus sauda dan madu sebagai alternatif perawatan ulkus diabetik. Sehingga penelitian tersebut diharapkan dapat menjelaskan hasil penggunaan kombinasi keduanya, dosis yang diperlukan,waktu yang dibutuhkan untuk rawatan menggunakan kombinasi serta manfaat lainnya yang dapat dihasilkan dari penggunaan kombinasi habbatus sauda dan madu sebagai alternatif topikal perawatan ulkus diabetik.

\section{KESIMPULAN}

Banyak metode perawatan alternatif yang telah ditawarkan untuk menyelesaikan ulkus diabetik, diantaranya adalah penggunaan habbatus sauda dan madu. Perawatan dengan menggunakan kombinasi keduanya dapat menjadi pilihan dikarenakan komponen yang dimiliki oleh keduanya sesuai dengan prinsip manajemen ulkus diabetik. Selain itu biaya yang harus dikeluarkan oleh pasien dan keluarga pun tidak begitu besar. Oleh karena itu diharapkan kombinasi ini dapat menjadi salah satu solusi perawatan alternatif ulkus diabetik dan dapat mempercepat penyembuhan ulkus, sehingga risiko amputasi pun dapat diminimalisir.

\section{DAFTAR RUJUKAN}

1. Anshori, Nuril Hudha Al.,dkk. "Pengaruh Perawatan Luka Menggunakan Madu terhadap Kolonisasi Bakteri Staphylococcus aureus pada Luka Diabetik Pasien Diabetes Mellitus di Wilayah Kerja Puskesmas

Rambipuji Kabupaten Jember." Jurnal Pustaka Kesehatan 9:3(2014): 500-504

2. Artanti,Puji,dkk. "Angka Kejadian Diabetes Mellitus Tidak Terdiagnosis pada Masyarakat Kota Pekanbaru". Jom FK 2:2(2015): 1-6

3. Budiharto et al. "Literatur Review: Bahan Alam yang Berpotensi dalam Topikal Agen untuk Perawatan Luka." Jurnal Keperawatan Respati 2:1(2015): 6-7

4. Hasan, Nor'Aishah,et al. "Antimicrobial Activity of Nigella sativa Seed extract (Aktivisi Antimikrob Ekstrak Nigella sativa). Sains Malaysia 42:2(2013): 143-147

5. Hermin.,dkk. "Analisis Teknik Perawatan Luka pada Penderita Diabetes Mellitus di RSUP Dr. Wahidin Sudirohusodo Makassar." 1:1(2012): 2-6

6. Isworo et al. "Hubungan Depresi dan Dukungan Keluarga Terhadap Kadar Gula
Darah pada Pasien Diabetes Mellitus Tipe 2 di RSUD Sragen." Jurnal Keperawatan Soedirman 5:1(2010): 37-46

7. Jamil, Ahmad Shobrun, et al. "Aktivitas Antimikroba Ekstrak Biji Nigella sativa terhadap Viabilitas Bakteri Probiotik Secara InVitro dan InVivo." Pharmacy 11:2(2014): 216-217

8. Kristiyaningrum.,dkk."Efektivitas Penggunaan Larutan $\mathrm{NaCl}$ dibandingkan dengan d40\% terhadap Proses Penyembuhan Luka Ulkus DM di RSUD KUDUS." JIKK 4:2(2013): 54-56

9. Kuswandi, Asep., dkk. "Efektivitas Kompres lodineTerhadapZonaHambat StaphylococcusaureuspadaUlkus Diabetikum." Jurnal Keperawatan Indonesia 16:3(2013): 139-144

10. Mardiati et al. "Ekstrak Cacing Tanah sebagai Inovasi Penyembuhan Ulkus Diabetik Berbasis Induksi Densitas Akson." (2013)

11. Marlinda, Lita. "Effectivity of Black Cumin Seeds Extract to Increase Phagocytosis". J Majority 4:3(2015): 58-64

12. Marvinia, Salia \& Widaryati."Efektivitas Metode Perawatan Luka Moisture Balance Terhadap Penyembuhan Luka pada Pasien Ulkus Diabetikum." Jurnal Kebidanan dan Keperawatan 9:1(2013): 29-36

13. Mulya, Adelse Prima \& Betty. "Hubungan Pengetahuan dan Motivasi Penderita Diabetes Mellitus dengan Upaya Pencegahan Ulcus diabetikum di Poli Penyakit Dalam Rumah Sakit Achmad Mochtar Bukittinggi." Jurnal Kesehatan STIKes Prima Nusantara Bukittinggi 5:1(2014): 92-103

14. Pramana, Radiant Eka, Suryani, Maria.,\& Supriyono, Mamat. "Efektivitas Pengobatan Madu Alami terhadap Penyembuhan Luka Infeksi Kaki Diabetik (IKD) (Studi Kasus Puskesmas Bangetayu dan Puskesmas Genuk Semarang." (2012). 17 Juni 2017 <http://www.download.portalgaruda.org> ,

15. Sulistianingsih et al. "Sensitivitas Antibiotik Terhadap Bakteri yang Diisolasi dari Ulkus Diabetik di RSUD Abepura, Kota Jayapura." Jurnal Biologi Papua 6:2(2014): 53-59

16. Sunaryo, Tri \& Sudiro. "Pengaruh Senam Diabetik Terhadap Penurunan Resiko Ulkus Diabetik pada Pasien DM Tipe 2 di Perkumpulan Diabetik." Jurnal Terpadu IImu Kesehatan 3:(2014): 99-105

17. Wulandari, Indah.,dkk. "Pengaruh Elevasi EkstremitasBawahTerhadapProses

Penyembuhan Ulkus Diabetik." Jurnal IImiah Keperawatan STIKES Hang Tuah Surabaya 3:2(2012): 51-57

18. Yulistiani, Mustiah. "Pemberian Salep Jintan Hitam (Nigella sativa) $10 \%$ pada Proses Penyembuhan Luka Diabetik Berdasarkan Betes Jensen Scale." Medisains Jurnal IImiah IImu-IImu Kesehatan 15:1(2015): 4-14 
Nomor ISSN : 2338-4700 / SK no. 0005.0102/JI.3.2/SK.ISSN/2013.06 